Revista Iberoamericana, Vol. LXXVIII, Núm. 240, Julio-Septiembre 2012, 681-694

\title{
EL ENSAYO COMO FORMA EN EL RÍO SIN ORILLAS \\ DE JUAN JOSÉ SAER
}

\author{
POR \\ NiCOLÁs LUCERO \\ University of Georgia
}

"Es un libro de literatura, no es un libro de ensayo", se apresura a avisar, o corregir, Juan José Saer (Sobre literatura 18). Para probarlo basta cotejar El río sin orillas (1991) con los textos recopilados en sus libros El concepto de ficción (1997), La narraciónobjeto (1999) y Trabajos (2006), a los que Sergio Delgado se refiere como "el margen no narrativo" de la producción de un escritor que nunca pensó en tener una "obra ensayística" (185). A diferencia de esos ensayos "propiamente dichos", relativamente breves, muchos de los cuales pasan en limpio las ideas de Saer sobre narración, El río sin orillas no se sale del cauce narrativo de su obra ni se distingue de un mismo "repertorio" de textos en los que la prosa alberga la reflexión y la iluminación poética. ${ }^{1}$ A la hora de elaborar los materiales que congrega para escribir sobre el Río de la Plata, Saer se piensa como un narrador que debe realizar ajustes o replantear su "estrategia" (19) pero sin abandonar los límites de la narración.

Ni ensayo, ni estudio, ni ficción (al menos voluntaria), ni no-ficción, ni autobiografía, ni reportaje. Saer define El río sin orillas mediante una abigarrada serie de negaciones y decide subtitularlo "tratado imaginario", una leyenda que alerta contra lecturas que busquen en él los protocolos de verdad de los géneros y discursos que contempla y descarta. La fórmula no carece de ambigüedades: ${ }^{2}$ el énfasis está menos en el supuesto rigor conceptual y sistemático del tratado que en el atributo de imaginario que abre la escritura a un orden más ancho y flexible donde darse una organización y forjarse un método que le sean propios. Lo imaginario del tratado alude a los materiales que el escritor convoca pero también a la forma en que los aborda y articula. Por un lado, El río sin orillas explora (y no pocas veces refuta) los imaginarios sociales: creencias,

1 En "Saer, nota y sinfonía”, Julio Premat habla de "repertorio", término que "evoca modelos musicales" para describir cómo la obra de Saer se configura a partir de una redistribución particular y reconocible de elementos (265).

2 La contratapa de la primera edición del libro abisma aun más la indeterminación. Allí se aclara que El río sin orillas sigue un "orden propio" que tampoco es el del "tratado". 
mitos y lugares comunes, sobre todo aquellos que nutren los espejismos de identidades afirmativas y que son especialmente vulnerables a la propaganda nacionalista o turística. Pero también imaginario es un método que no se abstiene de las dichas de la curiosidad y la digresión, que privilegia desplazamientos y conexiones horizontales para reunir objetos diversos, que se regodea en un despliegue proliferante de asociaciones y en la exageración de las interpretaciones.

Cabría preguntarse si acaso estas “estrategias de narrador” no se aproximan a la forma que tiene el ensayo de habérselas con los materiales que reúne para construir sus objetos, al menos en el sentido particular como Theodor Adorno vio su especificidad y su potencia crítica en la primera de sus Noten zur Literatur (1958), "El ensayo como forma". ${ }^{3}$ La lectura intensa y detallada que Saer hace de los escritos de Adorno no sólo se advierte en las citas que muestran coincidencias acerca de la función crítica de las vanguardias artísticas y el recelo intransigente ante las mercancías de la industria cultural, ${ }^{4}$ sino también en una presencia más ubicua y no menos decisiva: la fidelidad a una concepción negativa de la forma que Saer sigue escrupulosamente y que constituye para él una “[é]tica del rechazo como condición elemental para la propia escritura” (Premat, “Saer: un escritor” 193). ${ }^{5}$ La estética de Saer se vincula con la negatividad adorniana por la tenacidad con que revela los antagonismos que encubren las formulaciones identitarias, por ese consistente y encarnizado sentido de no-identidad de la dialéctica (Adorno, Negative Dialectics 5), que se resiste sin embargo a abandonar por completo un horizonte de reconciliación.

En "El ensayo como forma” Adorno procura menos definir un género que un programa filosófico y un método de escritura. ${ }^{6}$ Aun cuando El río sin orillas no sea un

Según cuenta en una entrevista en Princeton, Saer descubrió este volumen en una librería de Santa Fe en la década del sesenta (Riera 139-40). Además de ofrecer una lectura "innovativa e irreverente” de la relación entre arte y sociedad, algunos de esos ensayos de Adorno, como "La posición del narrador en la novela contemporánea” y “Signos de puntuación”, resultan afines a la estética de la narración que Saer elabora a fines de los sesentas y principios de los setentas. María Teresa Gramuglio remite al texto de Adorno sobre Marcel Proust para mejor entender “el tipo de conocimiento” al que apelan las narraciones de Saer ("Lugar" 181-82).

4 Sin ir más lejos, El río sin orillas se abre con una alusión circunstancial a la crítica de Adorno a las “mercancías musicales” (13) en Quasi una fantasia, que le da pie a Saer para considerar la banalidad del viaje contemporáneo y, por ende, las condiciones de enunciación de su texto sobre el Río de la Plata. La otra cita de Adorno en el libro es la célebre pregunta si es posible la poesía después del horror. Aparece en el pasaje del "Invierno" a la "Primavera”; me detengo en esa transición más adelante en este artículo.

5 Inspirándose en el título de Saer, Liliana Weinberg define la situación actual del ensayo latinoamericano como un "género sin orillas" (111). Plantea que se registra un pasaje en el género de "la forma de la moral" hacia "la moral de la forma", una tendencia en la que resalta "la recuperación de los fueros literarios propiamente dichos para el ensayo" (121).

6 Peter Hohendahl destaca la importancia que tiene "El ensayo como forma” dentro del pensamiento de Adorno: formula un modelo crítico para el intelectual alemán pos-revolucionario y esboza el programa filosófico que desarrollará luego en Dialéctica negativa y la inconclusa Teoría estética (222-24).

Revista Iberoamericana, Vol. LXXVIII, Núm. 240, Julio-Septiembre 2012, 681-694
ISSN 0034-9631 (Impreso) 
ensayo, y aun cuando difícilmente pueda reconocerse el estilo ensayístico de Adorno en sus páginas, ${ }^{7}$ interesa aquí apelar a su concepción del ensayo en tanto método para leer el "tratado imaginario" de Saer.

\section{VORACIDAD CRÍTICA}

Así describe Saer su método para El río sin orillas:

[U]n lugar es siempre más rico que su injusticia, su escarnio y sus violencias, y es justamente esa riqueza lo que hace a estos últimos intolerables. De ahí que en este libro haya un poco de todo, como cuando abrimos el cajón de un mueble viejo y encontramos, entremezcladas, reliquias que se asocian al placer o a la desdicha. Digamos que, habiendo recibido el encargo de construir un objeto significativo, abro el cajón, lo vuelco sobre la mesa, y me pongo a buscar y examinar los residuos más sugestivos, para organizarlos después con un orden propio, que no es el del reportaje, ni el del estudio, ni el de la autobiografía, sino el que me parece más cercano a mis afectos y a mis inclinaciones artísticas: un híbrido sin género definido, del que existe, me parece, una tradición constante en la literatura argentina -o en mi modo de interpretarla. (Río 18)

Todo comienza con un examen de las opciones disponibles pero desechadas, un repaso de aquello que el narrador podría pero decide no hacer para cumplir con el encargo de escribir sobre el Río de la Plata. “[L]a más íntima ley formal del ensayo es la herejía” ("Ensayo” 36), concluye Adorno. La hibridez de El río sin orillas es de índole negativa; proviene no del entusiasmo de la mezcla ni de una borrosa disolución de las fronteras entre géneros, sino de una indocilidad metódica que lleva a la construcción de un objeto nuevo. ${ }^{8}$ La singularidad del texto dentro del repertorio de Saer está dada por los reparos específicos que orientan su particular búsqueda formal y por el hecho de que esos problemas y esas reservas se exhiben más explícitamente que en sus otras narraciones.

7 Ecos de Adorno - de su estilo, de su ánimo provocativo e incluso de algunas de sus formulaciones teóricas-, se dejan oír en los ensayos que Saer escribe sobre la narración en la década del setenta, particularmente en varios pasajes de "Narrathon” (fechado en 1973, publicado en 1975): "La alienación [...] no está en la literatura que la refleja, sino en la que la escamotea, no está en la división vivida como división, sino en la división vivida como integridad. No está en Macedonio Fernández que teoriza, arduamente, la imposibilidad de narrar, sino en Vargas Llosa, que dedica trescientas páginas a describir la vida de un colegio militar, confundiendo la crítica liberal a un aspecto de la superestructura con una crítica de lo real. Es abriendo grietas en la falsa totalidad, la cual no pudiendo ser más que imaginaria no puede ser más que alienación e ideología, que la narración destruirá esa escarcha convencional que se pretende hacer pasar por una realidad unívoca” (Concepto 151).

8 El prólogo escrito por Sarmiento a sus Viajes en Europa, África y América (1849), que pasa revista a todo aquello que el escritor sudamericano ya no puede, no quiere o prefiere no hacer con el género de viajes, sugiere cuán fundada en la herejía está la tradición de los textos híbridos de la que habla Saer.

Revista Iberoamericana, Vol. LXXVIII, Núm. 240, Julio-Septiembre 2012, 681-694
ISSN 2154-4794 (Electrónico) 
Aese tiempo de ponderaciones y reticencias, en el que indaga tanto los inconvenientes que presenta la tarea como las promesas que ésta abre, Saer lo denomina "rumiación mental -apelación con que nuestro país ganadero designa cierto tipo de raciocinio mórbido” (Río 20). La paciente consideración de los obstáculos coincide con la revelación de que el encargo ha removido "visiones y posibilidades infinitas" en el escritor (Río 20). El "tratado imaginario" comienza entonces en el instante preciso en que el objeto, percibido en su opacidad, ejerce un magnetismo que lo atomiza y lo orienta hacia un terminus ad quem en el que convergen, "como se decía hasta hace poco, libertad y necesidad” (Río 20).

El río sin orillas arranca deteniéndose:

[T]odas esas biografías, memorias o reportajes que comercian con lo narrativo, suelen presentarse como el vehículo de la realidad más inequívoca y de la verdad más escrupulosa, sin que previamente sus autores hayan interrumpido unos minutos el flujo de sus experiencias tan verídicas para meditar un poco sobre los conceptos de verdad y de realidad. (Río 19)

En un mismo movimiento, Saer exaspera las cautelas respecto de fuentes, datos, géneros y teorías, y muestra a la vez una extraordinaria capacidad de absorberlos. Esa conjunción de voracidad y extrema precaución, con la que desmenuza, discierne y tritura todo lo que viene a cuento del objeto que se propone tratar, es uno de los rasgos de El río sin orillas más afines al ensayo como forma. La autorreflexividad aguda y perseverante, que cuestiona y frena el discurso, ${ }^{9}$ se une con una notable fluidez en la exposición, combinación que es otra de las aporías mediante las cuales Adorno define el ensayo: "La fácil docilidad del curso de los pensamientos del ensayista le obliga a una intensidad mayor que la del pensamiento discursivo, porque el ensayo no procede, como éste, ciega y automatizadamente, sino que en cada momento tiene que reflejarse sobre sí mismo” (35).

Inmovilidad autorreflexiva y fluidez, herejía y docilidad confluyen en El río sin orillas gracias al uso de una voz hipercrítica y socarrona que no cesa de "rumiar" sobre su propia cohesión y sobre cada uno de los escollos con los que tropieza, ninguno de los cuales parece escamotear en su recorrido, empezando por el encargo comercial que le da origen al texto. Es ésta una circunstancia particularmente problemática, sobre todo si tenemos en cuenta que "[...] el ensayo no admite que se le prescriba su competencia” (Adorno, "Ensayo” 12). Saer responde al encargo planteándose primero qué es un

9 La interrupción y la cesura son nodales en la poética narrativa de Saer. Gabriel Riera observa cómo Saer expone la percepción a una "duda metódica” y también cómo en algunos de sus textos, tal el caso de Glosa, apela a una "retórica de la rectificación", que consiste en "un ajuste permanente entre las dimensiones constatativas y performativas de la narración” (22-23, traducción mía).

Revista Iberoamericana, Vol. LXXVIII, Núm. 240, Julio-Septiembre 2012, 681-694
ISSN 0034-9631 (Impreso) 
encargo, sondeando las tensiones que lo atraviesan y discutiendo el margen que un escritor sudamericano tiene para rechazarlo o desviarlo. Pero también la insistencia en que El río sin orillas parte de un encargo desnuda los orígenes contingentes de su escritura y, simultáneamente, redobla la necesidad de dar con una forma propia para resolverlo. La no identidad entre exposición y cosa, que "impone a la exposición un esfuerzo ilimitado” y es lo que "en el ensayo resulta parecido al arte” (Adorno, “Ensayo” 29), se amplía e intensifica en El río sin orillas dada la latitud misma del pedido: escribir sobre un río. Saer le da vueltas al tema, busca diversos modos de aproximación, lo extravía cómicamente. La vasta apertura de un río sin orillas funciona como la mayor "constricción de la cosa" (Adorno 28), que le da un “orden propio” al texto. Se trata de una responsabilidad frente al objeto tomada tan en serio que acaba por ridiculizar el encargo.

La responsabilidad única del ensayista es con el objeto, dice Adorno ("El ensayo" 14), y no sorprende que el lector no ocupe un rol en su concepción de la forma y que sus ensayos parezcan dirigidos a nadie. Eduardo Grüner observa que para Adorno el "primer movimiento del ensayo es [...] resistir el espejismo de una comunicabilidad inmediata” (159). La crítica de la inmediatez comunicativa es también uno de los pilares de la estética de Saer. Sin embargo, la reflexión sobre los eventuales lectores de El río sin orillas tiene un lugar prominente en su "estrategia de narrador". Saer anticipa las respuestas de lectores idiotas o legos y conocedores o "no idiotas” como un problema a resolver (20-22). Al tiempo que crea una intimidad deliberada con el lector, el narrador continuamente lo interpela, incomoda y desestabiliza, impidiendo que se identifique con cualquier presunción de saber y superioridad fundada en ser argentino o europeo. La bifurcación del enunciatario tiene un efecto anamórfico en el lector, que acecha insidiosamente "el empecinamiento [...] de no querer ver más que el lado autocomplaciente de las cosas” (Saer, Río 114). La escisión entre un público argentino y otro europeo resulta un ardid para cuestionar, alternativamente, ambas posiciones, y prueba ser un falso dilema: “[M]e gustaría que este libro no se distinga en nada de los que ya he escrito, de narrativa o de poesía, sobre todo porque, al igual que ellos, no se dirige a ningún lector en particular, ni especialista ni lego ni argentino ni europeo” (Río 22). El único compromiso del ensayo es con el objeto; el ensayista no escribe para nadie. Saer reformula los corolarios de esa ética: como el único compromiso se establece efectivamente con el objeto y la única constricción es el ancho río, El río sin orillas se dirige, específica, concreta y materialmente, a cualquier lector.

VUELTA: ENSAYO Y ORIGEN

El río sin orillas arranca in medias res, en medio de un viaje en avión de Saer de vuelta de Francia a la Argentina, ocasión que no tarda en abrirse a evocaciones de otros viajes al Río de la Plata, propios y ajenos. El regreso al lugar de los afectos es un tópico revisitado por la escritura de Saer. Este comienzo no hace sino detenerse a problematizar

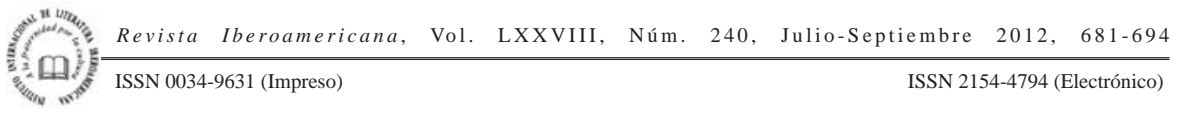


la vuelta y desmitificar su aura: "Es sabido que el mito engendra la repetición y que la repetición la costumbre, y que la costumbre el rito y que el rito el dogma; y que el dogma, finalmente, la herejía” (Río 13-14). Al dilema de cómo escribir un texto sobre un río, Saer responde narrando las vueltas que requiere su escritura.

No es que el viaje proporcione un orden narrativo para la organización de los materiales, ni siquiera a la manera arborescente en la que Claudio Magris resuelve su propio río, el Danubio, en un proyecto que “vuole portare all'inesorabile ordine del trattato, l'imprevedibilità del viaggio, l'intrico e la dispersione dei sentieri, la casualità delle soste, l'incertezza della sera, l'asimmetria di ogni percorso"'(11). El nomadismo singular del "tratado imaginario" de Saer consiste más bien en una serie de rodeos alrededor del lugar de su pesquisa, mediante los cuales va convocando y superponiendo anotaciones de sus propios cuadernos y las observaciones "invariables y contradictorias" (Río 25) de los muchos viajeros que, estando de paso por el lugar, dejaron sus impresiones sobre él. El texto no avanza según avanza el viaje, sino que se interrumpe en los momentos en que se disocia ese dilatado y fluido objeto, como se paran los viajeros a contemplar una planicie, el color de las aguas del río o las figuras que dibujan en el mapa los contornos de los accidentes del terreno.

El cuestionamiento radical de los orígenes está en la base de "El ensayo como forma”. En su disputa contra Martin Heidegger y contra la interrogación de las causas primeras en la filosofía (y contra la rigidez de los esquemas conceptuales que esas búsquedas primordiales generan), Adorno replica con la forma del ensayo: “[...] la misma originariedad es para el ensayo objeto de reflexión, algo negativo" ("Ensayo" 31). Que el ensayo sea un texto sobre otros textos, que su particular esfuerzo exhiba "[...] el ocio de lo infantil, que se inflama sin escrúpulos con lo que ya otros han hecho" ("Ensayo" 12), corroe e invalida las nociones de creación y origen. El ensayo viene a ocupar, festivamente, una posición intersticial, que "se sitúa entre las di-versiones" ("Ensayo" 12) de otras escrituras.

Lo que comienza en El río sin orillas como el relato de un viaje de regreso muy pronto se convierte en la sinuosa persecución de las huellas dejadas por otros viajeros y cronistas sobre el río y sus adyacencias. Las intermediaciones testimonian el fracaso y la desconfianza que genera la posibilidad de una experiencia directa: “Así va el mundo: la cosa parece próxima, inmediata, pero hay que dar un rodeo largo para llegar a rozarla, siquiera fugazmente, con la yema de los dedos. Nada de lo que nos interesa verdaderamente nos es directamente accesible" (Río 33). La escritura oscila entre la constatación de que el paisaje del río es “mudo" y "refractario a toda evocación” (32), tabula rasa que no permite primera inscripción alguna, y el arrebato que ocasiona la sensación de que sus aguas abren para el escritor "un abismo turbulento" (40).

De todas las heterogéneas fuentes de las que echa mano Saer para escribir su libro (textos de viajeros, historiadores, cronistas, ensayistas, cartógrafos, teóricos, poetas,

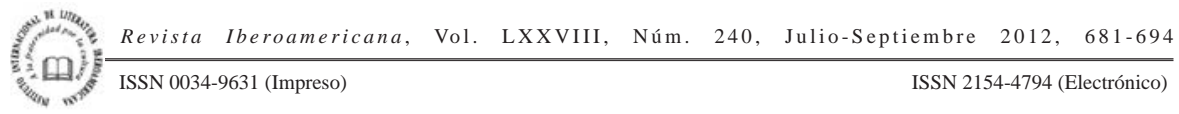


notas de viaje propias, recuerdos, conversaciones con amigos), se destaca su carácter "intermediario", por el cual funcionan, fragmentarias e intermitentes, como huellas y no como evidencias plenas. La bibliografía no cumple con una función documental; cada texto es tratado como reliquia de una experiencia empírica que se sustrae y se aleja, y sólo asoma en esas huellas, a la vez precarias y tumultuosas.

Saer admira y rescata en los escritos de sus "tíos viajeros" (Charles Darwin, George Chaworth Musters, Alfred Ebelot, Witold Gombrowicz) la curiosidad, la sensatez, la justicia de sus apreciaciones y, fundamentalmente, su "mirada exterior, al mismo tiempo imparcial y benévola” (Río 107), el lugar exotópico que los vuelve testigos privilegiados del error. Sus aciertos tienen valor en la medida que refutan las imágenes que, cristalizadas en mitos, estereotipos y prejuicios, sostienen identidades afirmativas basadas en supuestas diferencias y esencias irreductibles. ${ }^{10} \mathrm{El}$ narrador ensayista se regodea en citar y cotejar: "Uno de los mayores placeres de la lectura es encontrar la descripción de un mismo objeto tratado por autores diferentes [...]" (Río 135). Sin embargo, si las divergencias prueban la comicidad del error y la falibilidad de la representación, los más lúcidos de estos textos también regalan observaciones que generan un sentimiento de persistencia y continuidad. Tal el caso del Viaje de un naturalista de Darwin, cuya lectura es un modo de "[...] revivificar y de comprender, no las leyes que rigen el mundo, sino sensaciones íntimas que parecían inseparables del propio ser y que van desplegándose en lo exterior, al mismo tiempo autónomas y familiares" (Río 103). El valor de la mirada de los viajeros reside, entonces, en su potencial crítico pero también en el hecho de que, en sus páginas, “[...] tenemos la impresión, maravillada y nítida, de que las cosas están siendo percibidas y nombradas por primera vez desde los comienzos del mundo" (Río 107).

Esta concepción poética de la palabra, en que "[c]on el nombre, la cosa comienza a ser brotando de lo indistinto" (Scavino 11), ${ }^{11}$ coexiste en El río sin orillas con el

${ }^{10}$ La insistencia en que el Río de la Plata es una región sin atributos desbarata las pretensiones de exotismo de nacionalistas y colonialistas; su capacidad crítica está en que ridiculiza los abusos del color local y en que una región tan pobre de cualidades, por lo difícil que resulta imaginársela, desafía cualquier representación. En la constelación del "tratado imaginario", la definición por lo indiferenciado hostiga y desbarata la postulación y el orgullo de la diferencia, y tiende a exaltar aquellos aspectos que verifican la propagación de lo neutro y la reiteración serial de lo mismo. La sublimación de esa pobreza o esa falta de atributos, desligada de su función refutativa, como mera diferencia y rasgo distintivo, corre el riesgo de convertirse ella también en un pintoresquismo.

${ }^{11}$ Scavino indaga esta concepción poética de la palabra en Saer y los nombres. Observa: "Logos apofántikos, lo llamaron algunos griegos: la palabra que muestra o hace aparecer lo que hasta entonces se mantenía oculto, olvidado, en una suerte de letargo o latencia, y que no atraía, en consecuencia, ninguna mirada, ninguna teoría. La propuesta de Saer se acerca en este aspecto a la formulada por Martin Heidegger cuando consideraba como sinónimos a los verbos griegos legein, alétheuien y poiein, vale decir, nombrar (pero también reunir o recolectar), descubrir (pero también decir verdad y, literalmente, des-olvidar) y hacer (pero también engendrar)" (11).

Revista Iberoamericana, Vol. LXXVIII, Núm. 240, Julio-Septiembre 2012, 681-694
ISSN 0034-9631 (Impreso) 
cuestionamiento radical de los orígenes, propio de la palabra ensayística. Poesía y ensayo entran en contacto en esta intersección conflictiva. Por un lado, la poesía le recuerda a la narración y al pensamiento los orígenes luminosos de la palabra, su instrumento. Los rodeos del ensayo, por su parte, no dejan olvidar que esa "impresión maravillada y nítida” de un instante originario es ella misma derivada, ya que surge de un hallazgo en lo que otros han escrito. En esa conjunción contradictoria se funda para Saer el doble imperativo de la palabra: el de negar y volver a nombrar por vez primera.

POSICIONES

"El ensayo es lo que fue desde el principio: la forma crítica par excellence, y precisamente como crítica inmanente de las formaciones espirituales, como confrontación de lo que son con su concepto, el ensayo es crítica de la ideología” (Adorno, "Ensayo" 30). "El ensayo como forma” circunscribe la posición crítica del intelectual a la práctica de escritura del ensayista. En ese lugar, que tradicionalmente ha ocupado la figura del pensador, Saer pone al viajero, al narrador, a quien inventa su propio método para lidiar con el error y nombrar las reiteraciones de lo mismo.

Los viajeros (y los poetas) son testigos contingentes, algunos por estar "de paso", otros por haber vivido en estas tierras como "entenados", escribiendo sobre ellas en una lengua extranjera. Los que podríamos considerar "héroes" del tratado (Ebelot, Gombrowicz, Juan L. Ortiz), aquellos a los que Saer les dedica breves semblanzas biográficas, se destacan por la ética y la lucidez de sus escritos. Con los ensayistas, en cambio, se muestra más esquivo. Si El río sin orillas se inserta en la "tradición del ensayo de interpretación nacional” (Riera 18), lo hace de soslayo y en discordia con cualquier fervor o zozobra esencialista dentro de esa tradición. No sorprende que sea Martínez Estrada el ensayista que Saer más admira:

Únicamente nuestros mejores pensadores, como Ezequiel Martínez Estrada, igualmente calumniado por nacionalistas emocionales y cientificistas extranjerizantes, comprendieron que un país no es una esencia que se debe venerar sino una serie de problemas a desentrañar e, inventando sus propios métodos, forjados de ese entrecruzamiento local y planetario, se abocaron a la tarea. (Río 96-97)

Disidencia, herejía e invención formal sintetizan la ética que Saer reconoce en Martínez Estrada, un escritor que no renuncia al exceso interpretativo ni a pensar en imágenes y que, como apunta Eduardo Grüner, genera "recorridos" que desarticulan las antinomias de los discursos autoritarios (170). El autor de Muerte y transfiguración de Martín Fierro, Martínez Estrada, también encarna el “ostracismo” y el “destierro”

Revista Iberoamericana, Vol. LXXVIII, Núm. 240, Julio-Septiembre 2012, 681-694
ISSN 0034-9631 (Impreso) 
que definen, según Saer, el lugar o el destino del intelectual argentino (Río 96-97), una marginalidad que puede considerarse afín a la mirada exterior de los viajeros. ${ }^{12}$

Esa "pasión de la distancia" en la que insiste Saer no debe confundirse con una enunciación que se ampara en la ecuanimidad ni en la moderación de sus convicciones. En el "Invierno" de El río sin orillas, Saer consagra varias páginas a la historia política argentina del siglo xx en las que da una visión lapidaria no sólo del genocidio de Estado, la corrupción financiera y política, y el imperialismo norteamericano, sino también de la volatilidad de las clases medias, del "menjunje paternalista y populista" del peronismo, de los "inefables" Montoneros, "masa obtusa de instinto de muerte, de oportunismo y de megalomanía”, y de la "ligereza” de algunos intelectuales durante la década del setenta (178-85). Por un lado, éste es el punto en el que el tratado imaginario más parece acercarse a un escrito de opinión, y por lo mismo, el momento en que más se alejaría de la negatividad del ensayo como método: el narrador "se debate" menos intensamente, cuestiona menos sus juicios, y asume una voz sentenciosa que oscila entre el desenfado de la sátira y la ira de una catilinaria. ${ }^{13}$ Pero también ése es el punto en el que se hace más patente el sesgo polémico de la escritura de Saer, ${ }^{14}$ por el cual la exotopía y la negatividad no implican prescindir de posiciones ni escudarse en una supuesta invulnerabilidad que confiera la distancia.

\section{TRANSICIONES: ENSAYO, NARRACIÓN Y FELICIDAD}

Adorno plantea la relación entre ensayo y felicidad de manera cabalmente contradictoria. Por la flexibilidad de la sintaxis, por la festiva exageración de las interpretaciones, por el frenesí asociativo, por el goce en la polisemia de las palabras y por ser una crítica permeable a la curiosidad, el ensayo es para Adorno una forma de la dicha: "La satisfacción que la retórica quiere suministrar al oyente se sublima en el ensayo hasta hacerse idea de la felicidad de una libertad frente al objeto, libertad que da al objeto más de lo suyo que si se le coloca en el despiadado orden de las ideas" ("Ensayo" 33). Si para la retórica éstos son meros recursos subsidiarios para ablandar al oyente y después mejor convencerlo, Adorno sugiere que el abandono de la

${ }_{12}$ Adorno ve en el anacronismo del ensayo un modo de resistencia crítica, especialmente frente a los discursos de las ciencias sociales (35). Para una lectura del anacronismo en los ensayos de Martínez Estrada ver Sarlo 129-35.

13 Tonos y géneros de la invectiva que, dicho sea de paso, no son ajenos a Adorno ni a Martínez Estrada.

14 Sobre el furor y el desenfado con los que Saer planteaba sus opiniones en sus comienzos como escritor, ver Miguel Dalmaroni, "Un iracundo a medio borrar: Saer en público, 1964”. Ese estilo, que no desestima el humor y la hipérbole, aparece en sus ensayos y en la voz de narradores y personajes en sus ficciones, constituyendo un elemento reconocible de su "repertorio".

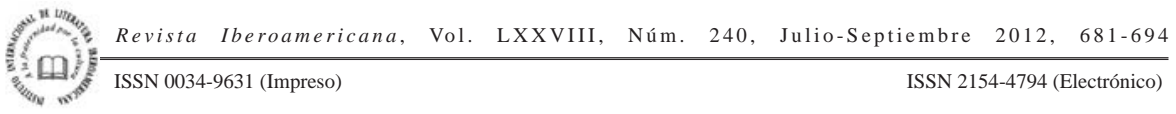


subordinación conceptual y de la lógica discursiva no son accesorios sino que forman parte del contenido de verdad del ensayo ("Ensayo" 33).

La felicidad que nos causa la lectura de El río sin orillas tiene que ver con esa libertad frente al objeto de la que habla Adorno y que se advierte, sobre todo, en la agilidad y el descaro de las transiciones. Un índice de materias por el que el texto va pasando, “dócilmente”, nos permitiría apreciar con toda nitidez cuán flexible, singular y hasta improbable es la coordinación de esos contenidos. Cinco páginas de "Verano" recorren la fundación del fuerte de Sancti Spiritus, el recuerdo de una mordida de sanguijuela cuando el narrador tenía cinco años, una reflexión sobre la precariedad y la pobreza del lugar, la indiferencia de sus habitantes por el río, el origen romántico de la pampa, la historia de sus nombres y de su formación geológica, el agrupamiento de las especies en la llanura, la organización serial del mundo (58-63). Diez páginas del "Otoño" se detienen a meditar sobre las paradojas y los amplios significados de la toponimia, y a registrar la poesía que regalan algunos de esos nombres (107-16). Es que "[la] libertad en la elección de los objetos [...] se debe al hecho de que para el ensayo todos los objetos están en cierto sentido a la misma distancia del centro, del principio que los embruja a todos” (Adorno, “Ensayo” 31). El río sin orillas no distingue jerarquías; no sólo se inclina por detalles fugaces o "menores" sino que encuentra siempre el chiste o la nota irónica oportuna para disminuir todo dato o juicio que sea pasible de exaltación nacionalista.

Todos esos objetos se van yuxtaponiendo e intrincando como el tejido de un tapiz, para emplear la metáfora que usa Adorno para el ensayo ("Ensayo" 23). Así como el círculo, el espiral o el enjambre emergen como figuras metanarrativas en algunas ficciones de Saer, El río sin orillas también va sembrando imágenes en su recorrido que sugieren la disposición de los materiales en el texto. Las migraciones y la propagación de lo mismo en colonias geométricas y contingentes, o las "limaduras de hierro arracimadas en la punta de un imán” (94), que cifran el magnetismo de un río que repele y atrae con igual fuerza a sus habitantes, figuran también cómo se van agrupando los temas en el tratado.

Pero la configuración más evidente que rige la transición entre las partes en el texto son las estaciones, las de la naturaleza pero sobre todo las de la música. Julio Premat señala la importancia que tienen las referencias musicales en la literatura de Saer y propone que la "cadencia” es el modo como se configura su obra, una articulación que se percibe en las relaciones entre los distintos textos pero también, en un nivel microscópico, en “[...] esas largas frases, a la vez extensas, digresivas y de pulso seguro; frases que parecen poder integrar todo lo lateral y lo inédito, sin perder de vista su sentido" (Premat, "Saer" 171). ${ }^{15}$ El río sin orillas está organizado según las cuatro estaciones, una estructura que

15 "Más que de obra o de saga, el conjunto de los textos escritos por Juan José Saer podría calificarse de cadencia, es decir que esos textos se caracterizan por una frecuencia de producción, por una singular manera de avanzar, por un ritmo, por una continuidad que se prolonga de título en título" (Premat, "Saer: un escritor” 168).

Revista Iberoamericana, Vol. LXXVIII, Núm. 240, Julio-Septiembre 2012, 681-694
ISSN 0034-9631 (Impreso) 
le permite pasar de una tonalidad de los afectos a otra, conectando las partes y marcando a la vez cesuras entre ellas. Desde ya, esta disposición connota lo cíclico, pero el orden elegido, que comienza con el verano y termina con la primavera, modifica la secuencia más convencional que sigue el programa de las estaciones que, como los conciertos de Vivaldi, suele ir de la primavera al invierno, espejando así las etapas de la vida. Que el tratado culmine en la primavera es talvez indicio de una solución afirmativa o de un vago optimismo, aunque mitigado por el inexorable carácter cíclico que rige las transiciones. De hecho, el texto termina con una reflexión sobre el ritual del asado, que junta a los amigos y los reconcilia, aunque más no sea fugazmente, con lo sensorial y, sin embargo, el cierre mismo de ese final no es sino una cadencia a zonas menos radiantes, con esas voces que "van transformándose poco a poco en susurros hasta que por último, ya bien entrada la noche, inaudibles, se desvanecen” (Río 250).

La transición crucial de El río sin orillas es la que va del invierno de la violencia y el horror a la primavera de la poesía y la vida. Llegado este punto, Saer reitera, previsiblemente, la pregunta que plantea Adorno en Minima Moralia, "[...] la pregunta capital de este siglo: ¿es posible escribir poesía, es decir, aceptar la vida, después de Auschwitz?”, y marca su adhesión a la menos citada respuesta “afirmativa” (Río 207) que le da el mismo Adorno a ese dilema:

Todo lo que aun bajo el espanto prospera en belleza, es escarnio y detestable por sí mismo. Sin embargo, su efímera forma coadyuva en la tarea de evitar el espanto. Algo de esta paradoja está en el fundamento de todo arte, y hoy sale a la luz en el hecho de que el arte en general existe todavía. Una bien asegurada idea de lo bello exige que la felicidad sea rechazada y al mismo tiempo sostenida. (citado en Saer, Río 207)

Esta paradoja está también en la oscilación del ensayo entre la negatividad crítica y la felicidad, que Adorno termina por negarle. Aun de la felicidad fugaz del instante desconfía el ensayo: "Para la felicidad, que era sagrada para Nietzche, el ensayo no conoce más nombre que el negativo” (“Ensayo” 36).

¿Cómo entender la relación entre la negatividad ensayística de El río sin orillas y esas epifanías en las que el narrador se detiene y que traen una fuerte sensación de permanencia y dicha sensorial? Saer rememora y narra experiencias, las más extensas de las cuales son fragmentos que registran momentos tan efímeros y contingentes como reveladores, que crean una impresión imborrable de persistencia, de reconciliación entre lo interior y lo exterior, de identidad en lo mismo. Las huellas resecas de unos animales, una evocación de los “adoquines desiguales de Proust” y la presencia fortuita de un camión con ganado en una parada de buses crean en él una "sensación de familiaridad y pertenencia”, "una unidad en sí inmóvil y permanente, pero que contenía una diversidad vivaz y vívida de asociaciones, de imágenes, de emociones" (Río 76). Una "larga digresión” (214-18) cuenta la llegada de una mujer, unos niños y un caballo al río Paraná,

\footnotetext{
Revista Iberoamericana, Vol. LXXVIII, Núm. 240, Julio-Septiembre 2012, 681-694 ISSN 0034-9631 (Impreso) ISSN 2154-4794 (Electrónico)
} 
y cómo el narrador experimenta “cada una de las sensaciones” de la mujer cuando mete sus pies y sus muslos en el agua. Dada la exhaustividad con la que narra esos pasajes es en ellos donde más reconocemos el arte de la narración de Saer en El río sin orillas. El ensayo, como decía Lukács, está “dos veces alejado de la vida”. Estos paréntesis no devuelven el ensayo a la vida en virtud de una supuesta inmediatez de la experiencia “autobiográfica”; ${ }^{16}$ son, en cambio, rodeos narrativos que, pasando por Proust, Heráclito, Enesidemo y Epicuro, revierten la coda negativa de Adorno en "El ensayo como forma” y, en una concesión a Nietzche, dan con la felicidad en un momento de su recorrido.

En los ensayos de Saer sobre la narración, Sergio Delgado ve un narrador que intenta "regresar de inmediato, como un pez fuera del agua, al medio narrativo que le es propio" (179). Podríamos pensar que algo similar ocurre con los deslices narrativos de El río sin orillas, en esas epifanías súbitas y breves como larga y morosa es su escritura. Sin embargo, son justamente esos momentos fulgurantes del texto los que dan pie para las reflexiones más elaboradas sobre lo diverso y lo mismo, sobre la idea errónea de que la experiencia es inajenable y sobre la constatación de que "el Logos es común a todos” (Río 218). El momento en que la narración parece ganar mayor autonomía coincide con los tramos de reflexión más intensa en los que el tratado imaginario se acerca a un ensayo de estética. Este vínculo estrecho entre "la filosofía y el relato" en la literatura de Saer fue formulado por María Teresa Gramuglio en una reseña de 1983 sobre El entenado, texto en el que los “sucesos novelescos” están “asediados e interrogados por extensos pasajes que no es abusivo llamar filosóficos, donde predomina un discurso de reflexión que los rodea, obsesivo, para tratar de arrancarles su sentido" ("La filosofía y el relato” 35). Tan entrelazadas están la narración y la filosofía en la literatura de Saer que se hace difícil determinar cuál asedia a cuál. Para poder seguir narrando, el narrador debe pasar por la reflexión. Ésa es una fuerte convicción de Saer (y de Adorno), que aparece teorizada en sus ensayos sobre literatura y ensayada pacientemente en cada una de sus narraciones. Inclusive, dada la herejía obstinada y pormenorizada con que Saer aborda la tradición narrativa, no sería exagerado pensar que el ensayo como forma es, al menos parcialmente, la forma que asume la narración en su literatura. Pero también puede decirse que para poder seguir ensayando, para tratar con el concepto y lo no conceptual, para pensar en lo mismo y lo diferente, para dar cuenta del escarnio y también la dicha, el ensayo, según Saer, debe pasar por las vueltas de la narración.

La iluminación no es patrimonio del poema ni de la narración ni del ensayo. En la poética de Saer la epifanía es inextricable de la negación. El río sin orillas no se desliga de la discusión crítica de ideas y de conceptos, ni de las tensiones entre éstos y lo que no cabe en ellos. No rehúye ni de las aporías ni de los fulgores de la nominación, tampoco

${ }_{16}$ Julio Premat sugiere leer El río sin orillas en relación con una "nueva autobiografía”, en consonancia con "la importante dimensión autobiográfica" en escritores del nouveau roman como Alain Robbe-Grillet y Nathalie Sarraute (Dicha 434).

ISSN 0034-9631 (Impreso) 
de convicciones estéticas y políticas, muchas de ellas provocadoras y controvertidas, que destierran la posibilidad de un relativismo laxo y autocomplaciente. Si celebra la herejía, la exageración y una jocosa "irresponsabilidad" respecto de saberes, instituciones y disciplinas, lo hace sin perder de vista la tarea de separar lo falso de lo verdadero. En esa tenacidad está el influjo más notorio de "El ensayo como forma” en El río sin orillas.

\section{BiBLIOGRAFÍA}

Adorno, Theodor W. "El ensayo como forma”. Notas de literatura. Manuel Sacristán, trad. Barcelona: Ediciones Ariel, 1962. 11-36.

Minima Moralia: Reflections on a Damaged Life. Londres: Verso, 2010.

Negative Dialectics. E. B. Ashton, trad. Nueva York: Continuum, 1995.

Dalmaroni, Miguel. "Un iracundo a medio borrar: Saer en público, 1964”. Actas del Segundo Congreso Internacional de Literatura CELEHIS, 2004. < www.freewebs. com/celehis/actas2004/conferencias/E/2_Dalmaroni.doc>. 1 dic. 2010.

Delgado, Sergio. "Saer ensayista”. Le lieu de Juan José Saer / El lugar de Juan José Saer. Actes 10. Milagros Ezquerro, ed. Montpellier: Éditions du Centre d'études et de Recherches Sociocritiques, 2002. 175-86.

Gramuglio, María Teresa. “El lugar de Saer”. Juan José Saer por Juan José Saer. Buenos Aires: Celtia, 1986. 261-307.

“La filosofía y el relato". Punto de vista 20 (1984): 35-36.

Grüner, Eduardo. Un género culpable. La práctica del ensayo: entredichos, preferencias e intromisiones. Rosario: Homo Sapiens, 1996.

Hohendahl, Peter Uwe. "The Scholar, the Intellectual, and the Essay: Weber, Lukács, Adorno, and Postwar Germany”. German Quarterly 70/ 3 (1997): 217-32.

Magris, Claudio. Danubio. Milán: Garzanti, 1986.

Martínez Estrada, Ezequiel. Muerte y transfiguración de Martín Fierro; ensayo de interpretación de la vida argentina. México: Fondo de Cultura Económica, 1958.

Premat, Julio. La dicha de Saturno: escritura y melancolía en la obra de Juan José Saer. Rosario: Beatriz Viterbo, 2004.

“Saer, nota y sinfonía”. Répertoire. Valentina Litvan y Marta López Izquierdo, eds. Número especial de Pandora 7 (2008): 265-78.

"Saer: un escritor del lugar". Héroes sin atributos. Figuras de autor en la literatura argentina. Buenos Aires: Fondo de Cultura Económica, 2008. 167-202.

Riera, Gabriel. The Littoral of the Letter. Saer's Art of Narration. Lewisburg: Bucknell UP, 2006.

Saer, Juan José. El concepto de ficción. Buenos Aires: Seix Barral, 2004. La narración-objeto. Buenos Aires: Seix Barral, 1999.

El río sin orillas. Tratado imaginario. Buenos Aires: Alianza, 1991. Sobre literatura. São Paulo: Humanitas Publicações / FFLCH, 2000.

Revista Iberoamericana, Vol. LXXVIII, Núm. 240, Julio-Septiembre 2012, 681-694
ISSN 2154-4794 (Electrónico) 
Trabajos. Buenos Aires: Seix Barral, 2006.

Sarlo, Beatriz. "Ezequiel Martínez Estrada: Nueva lectura imposible”. Escritos sobre literatura argentina. Sylvia Saítta, ed. Buenos Aires: Siglo XXI, 2007. 129-35.

Sarmiento, Domingo Faustino. Viajes por Europa, África y América 1845-1847. Nanterre: ALLCAXX, 1993.

Scavino, Dardo. Saer y los nombres. Buenos Aires: El Cielo Por Asalto, 2004.

Weinberg, Liliana. "El ensayo latinoamericano entre la forma de la moral y la moral de la forma”. Cuadernos del CILHA 8/9 (2007): 110-29.

ISSN 0034-9631 (Impreso) 